\title{
Essay
}

\section{Writing-to-Learn in Undergraduate Science Education: A Community-Based, Conceptually Driven Approach}

\author{
Julie A. Reynolds, ${ }^{*}$ Christopher Thaiss, ${ }^{\dagger}$ Wendy Katkin, ${ }^{\ddagger}$ \\ and Robert J. Thompson, Jr. ${ }^{\S}$
}

*Department of Biology, Duke University, Durham, NC 27708; ${ }^{+}$University Writing Program, University of California, Davis, Davis, CA 95616; ${ }^{\ddagger}$ The Reinvention Center, University of Miami, Coral Gables, FL 33146; $\S$ Department of Psychology and Neuroscience, Duke University, Durham, NC 27708

Submitted August 1, 2011; Revised October 18, 2011; Accepted November 7, 2011

Monitoring Editor: Robin L. Wright

\begin{abstract}
Despite substantial evidence that writing can be an effective tool to promote student learning and engagement, writing-to-learn (WTL) practices are still not widely implemented in science, technology, engineering, and mathematics (STEM) disciplines, particularly at research universities. Two major deterrents to progress are the lack of a community of science faculty committed to undertaking and applying the necessary pedagogical research, and the absence of a conceptual framework to systematically guide study designs and integrate findings. To address these issues, we undertook an initiative, supported by the National Science Foundation and sponsored by the Reinvention Center, to build a community of WTL/STEM educators who would undertake a heuristic review of the literature and formulate a conceptual framework. In addition to generating a searchable database of empirically validated and promising WTL practices, our work lays the foundation for multiuniversity empirical studies of the effectiveness of WTL practices in advancing student learning and engagement.
\end{abstract}

\section{INTRODUCTION}

A significant challenge in science education is how to move students from thinking about science as a collection of facts to be memorized toward a deeper understanding of concepts and scientific ways of thinking. Within undergraduate science, technology, engineering, and mathematics (STEM) education, one approach that has garnered considerable attention is learning-to-write-strategies designed to improve student scientific writing (Moskovitz and Kellogg, 2011). In contrast, there has been a relative neglect of writing-to-learn (WTL)using writing to improve student understanding of content, concepts, and the scientific method. Despite substantial evidence that writing can be an effective tool in student learning

DOI: $10.1187 /$ cbe.11-08-0064

Address correspondence to: Julie A. Reynolds (jar88@duke.edu).

(C) 2012 J. A. Reynolds et al. CBE-Life Sciences Education (C) 2012 The American Society for Cell Biology. This article is distributed by The American Society for Cell Biology under license from the author(s). It is available to the public under an AttributionNoncommercial-Share Alike 3.0 Unported Creative Commons License (http:/ / creativecommons.org/licenses/by-nc-sa/3.0).

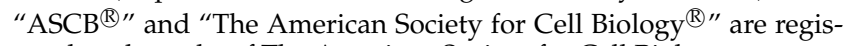
tered trademarks of The American Society for Cell Biology. and engagement (e.g., Poirrier, 1997; Bangert-Drowns et al., 2004; Brewster and Klump, 2004; Thaiss and Zawacki, 2006; Carter et al., 2007; Graham and Perin, 2007; National Survey of Student Engagement, 2008) and that WTL strategies can enhance knowledge acquisition and cognitive skill development in science disciplines (Rivard, 1994), WTL practices are still not widely implemented.

Rivard's insightful review of WTL in science disciplines identified several key issues that impede widespread acceptance and application of research findings. Since different types of writing tasks result in different kinds of learning, we need to determine the links between writing and both critical thinking and conceptual change. Furthermore, writing practices need to be studied in context, rather than in isolation, and research designs need to examine the interactions among specific learning objectives, personal characteristics (e.g., prior knowledge), models of instruction (coverage vs. conceptual understanding), and specific writing tasks. The underlying metacognitive processes necessary for learning specific types of knowledge (declarative, procedural, and conditional) also must be identified and targeted by corresponding WTL strategies. Since higher-order thinking involves restructuring knowledge, we need to determine what types of writing activities evoke this process of knowledge 
transformation. Moreover, systematic, action-oriented research involving both qualitative and quantitative studies is needed to bridge the gap between researchers and practitioners. All these issues are still relevant today.

Given the promise of WTL and the specificity of Rivard's recommendations for further research, what accounts for the lack of progress in the intervening $18 \mathrm{yr}$, and what new approaches will be needed going forward? We argue that two of the major deterrents to progress are the lack of a community of science faculty committed to undertaking and applying the necessary research, and the absence of a conceptual framework to systematically guide study designs and integrate findings. A third deterrent is the continuing disconnect between research and practice, which prevents instructors from identifying and incorporating appropriate WTL interventions. In an effort to address these issues, we undertook an initiative, supported by the National Science Foundation (NSF) and sponsored by the Reinvention Center (a consortium of 65 U.S. research universities dedicated to the improvement of undergraduate education at research universities), to build a community of WTL/STEM educators who would undertake a heuristic review of the literature and formulate a conceptual framework to guide collaborative studies and educational practices.

\section{A COMMUNITY-BASED APPROACH}

Although we acknowledge that some writing pedagogies can be resource-intensive to implement, there are ample sources highlighting more efficient and equally effective strategies for responding to student writing (e.g., Spear, 1987; Thaiss, 1998; Elbow and Belanoff, 1999; Ferris, 2003; Russell, 2005; Volz and Saterbak, 2009; Bean and Weimer, 2011). Therefore, we began with the premise that STEM faculty reluctance to incorporate writing in their courses derives largely from a lack of awareness of the research on the effectiveness of WTL, since most published findings are in journals not regularly read by STEM faculty and the majority of studies use methods unfamiliar to most scientists. Rather than simply reviewing the literature yet again and delivering "take-home messages" to STEM faculty (a traditional approach), we hypothesized that a more effective approach would be to engage STEM faculty directly in identifying promising WTL practices that improve undergraduate learning in STEM education (a community-based approach).

Our first step in building community was to form a WTL working group made up of 12 well-known experts in STEM research and education (Table 1). Its members formulated the intellectual framework for the project and conducted a heuristic review of the literature that had four specific objectives: 1) create a searchable database of WTL resources for both educators and researchers; 2) identify empirically validated and promising WTL practices; 3) determine critical gaps in current knowledge; and 4) lay the foundation for multi-university empirical studies of the effectiveness of WTL practices in improving student learning in STEM disciplines.

The second step was to engage the STEM community in discussion of the most promising findings of the heuristic review and the implications for educational practice and research. Our method was to offer a workshop on WTL in STEM at the Reinvention Center 2010 Conference. The workshop was at- tended by 80 STEM faculty (the majority of whom were nominated by their universities' Vice Provosts) who collectively considered how effective and promising WTL approaches could be applied in courses they teach, and who developed recommendations for the next steps in the research process to advance understanding of effective uses of WTL practices in STEM education. The postworkshop evaluation survey responses $(n=30)$ indicated that $76 \%$ of participants believe WTL will be an effective new tool in strengthening their students' engagement; $90 \%$ expressed openness to experimenting with WTL practices and encouraging their colleagues to do so also; $79 \%$ expressed readiness to play a leadership role in the development of WTL at their institutions.

These findings attest to the value of the community-based approach. More specifically, by engaging the STEM community in both formulating the conceptual framework for the review of the literature and also in processing the findings with regard to the implications for both practice and subsequent research, we brought to bear a more diverse and inclusive perspective and yielded a set of recommendations more ready for implementation than the traditional approach of a single reviewer providing "take-home messages." Furthermore, the community-building process resulted in faculty not only expressing their readiness to participate in the development and implementation of WTL practices on their campuses but also undertaking planning of multi-university collaborative initiatives.

\section{CONCEPTUAL FRAMEWORK: CONNECTING WTL, NEUROCOGNITIVE DEVELOPMENT, LEARNING, AND TEACHING}

Several key findings identified in the seminal National Research Council report How People Learn: Brain, Mind, Experience, and School (National Research Council, 2000) have implications for educational practices: Learning changes the physical structure and functional organization of the brain and people construct new knowledge and understanding based on what they already know and believe. These prior beliefs and knowledge can either facilitate or interfere with new learning. A related finding is that neurocognitive development continues through adolescence into adulthood, as the brain, particularly the prefrontal cortex, goes through a remodeling process; these changes in the brain are paralleled by changes in the cognitive abilities supported by these regions, particularly the development of cognitive skills involved in executive functions, social cognition, and self-regulation (Blakemore and Chowdhury, 2006). This ongoing remodeling of the brain is the dynamic context in which undergraduate educational experiences are both impacted by and contribute to the development of higher-order cognitive processes and evaluative thinking.

Recent theory directs attention beyond the first-order cognitive processes that enable us to know about the world to the second-order metacognitive- "knowing about knowing"processes that enable us to regulate cognitive, emotional, and motivational processes during learning (Kuhn, 1999). We now understand that successful learners are self-regulated, in that they employ a number of metacognitive processes while making meaning of information and their experiences. They elaborate on their existing knowledge, formulate relationships and 
Table 1. WTL working group members

Greg Bothun, Professor of Physics, University of Oregon

David Hanson, Distinguished Service Professor of Chemistry, Stony Brook University

Wendy Katkin, Founding Director (Emeritus), The Reinvention Center

Jeffery Kovac, Professor of Chemistry, University of Tennessee

Lisa McNair, Assistant Professor of Engineering Education, Virginia Polytechnic Institute

Tamara Moore, Assistant Professor of Curriculum and Instruction and Co-Director of the STEM Education Center at the University of Minnesota, Minneapolis

Marie Paretti, Associate Professor of Engineering Education, Virginia Polytechnic Institute

Julie Reynolds, Associate Director of Undergraduate Studies and Assistant Professor of the Practice in Biology, Duke University

Arlene Russell, Senior Lecturer in Chemistry, University of California at Los Angeles

Leslie Schiff, Professor of Microbiology, University of Minnesota, Minneapolis

Christopher Thaiss, Clark Kerr Presidential Chair, Professor, and Director of the University Writing Program, University of California, Davis Robert J. Thompson, Jr., Professor of Psychology and Neuroscience, Duke University

make connections among items, develop self-explanations, and monitor their own understanding and comprehension. There has been a corresponding paradigm shift in education from a focus on the curriculum and the acquisition of content knowledge to developing the learners' metacognitive skills and learning strategies (Mayer, 1992) by incorporating modeling to make thinking visible and disciplinary practices overt, providing graduated supported practice ("scaffolding"), and encouraging reflection. Writing affords one of the most effective means for making thinking visible, and WTL practices can foster learning of both content and modes of thinking characteristic of disciplinary experts.

These advances in understanding about how people learn provide the salient conceptual framework for a commonand compelling-research agenda that we propose take the following general form: What is the role of [specific WTL practice] in improving [disciplinary-specific learning objective] through impacting [specific cognitive, metacognitive, motivational, and/or emotional process], as a function of [context variables, such as course level and class size; discipline; level, background, and goals of students; and subdiscipline, local, and institutional factors]? Having a common conceptual framework for research enables STEM educators to undertake studies appropriate to their interests and particular context, while simultaneously participating in collaborative studies within and across universities, such that their findings contribute to the broader delineation and mapping of effective WTL practices.

\section{LITERATURE REVIEW}

Building on Rivard's review, we focused our review on empirical studies published after 1994 in which writing strategies were designed to improve undergraduates' learning in STEM disciplines. We examined 324 journal articles, books, book sections, conference proceedings, and reports that were identified through searches in the Web of Science and ERIC databases or suggested by the working group. Of these sources, 203 specifically focused on WTL pedagogies within STEM disciplines at the college level. We filtered studies through the lens of learning theory and used our conceptual framework to organize and categorize findings by level of course, discipline, and learning objectives. Representative studies reporting empirically validated practices, as well as descriptive studies that are promising and warrant further trials, were identified for each cell of the resulting matrix (Table 2). In addition, all studies were characterized by a number of additional key words to facilitate database searches (Table 3). The database is available at: http://bit.ly/fjudgo.

\section{IMPLICATIONS FOR FUTURE RESEARCH DIRECTIONS}

Our heuristic review found mostly descriptive case studies reporting on the effectiveness of particular WTL practices in improving students' learning. Building upon emerging efforts supported by the literature to move the research toward the analytical and experimental levels, we offer the following recommendations.

First, the role of writing in improving learning needs to be reconceptualized. Learning is no longer understood as simply "acquisition of knowledge," but as the construction of understanding and meaning as a result of social interaction. It is already well recognized that improving learning is no longer just a matter of strengthening associations and habits, but involves a change in understanding (Schoenfeld, 1999; Kuhn, 2005). The implications of writing assignments in STEM disciplines, therefore, should be reconceptualized to foster within students a shift from "knowledge telling" to "knowledge transforming" (Bereiter and Scardamalia, 1987).

Second, to establish the links between writing and both conceptual change and critical thinking within specific disciplines, learning objectives need to be operationally defined in terms of the disciplinary content, conceptual knowledge, or the "ways of thinking" that characterize experts in the field and must include the underlying processes proposed to mediate and moderate the effect of particular WTL practices on student learning (Table 2). Although there has been an enduring focus in higher education on developing critical thinking and reasoning as general skills across academic disciplines, research is increasingly providing support for the view that reasoning is situation or domain specific (Beyer et al., 2007)

Third, studies must specifically seek to delineate the "mechanisms of effect" that is, the way in which a particular WTL practice brings about an improvement in student learning. How does writing "cause" learning to occur? Is it simply a matter of increasing time on task, or do students learn by applying cognitive and metacognitive strategies while writing? In addressing these questions, four interrelated systems have been demonstrated to affect learning 


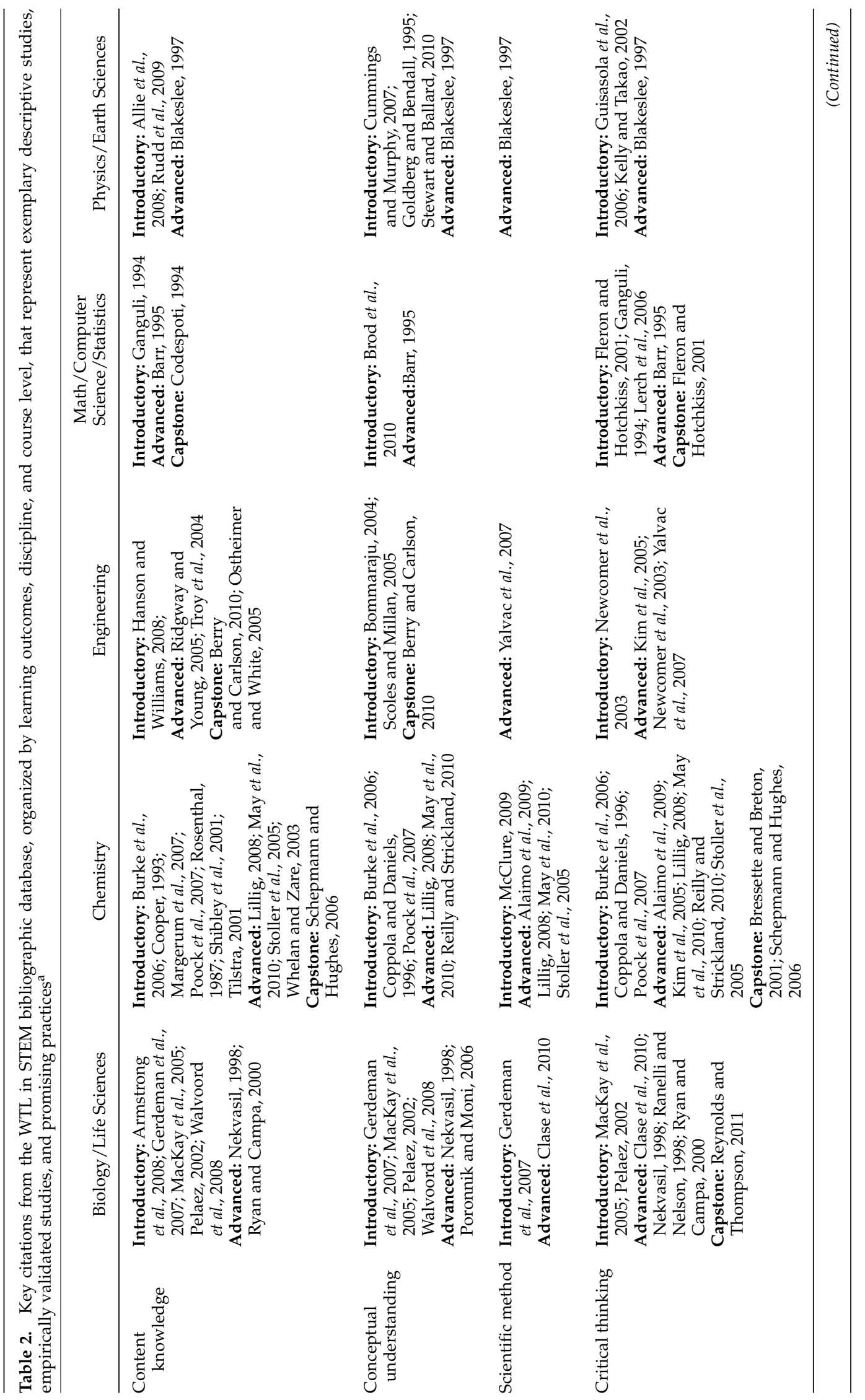




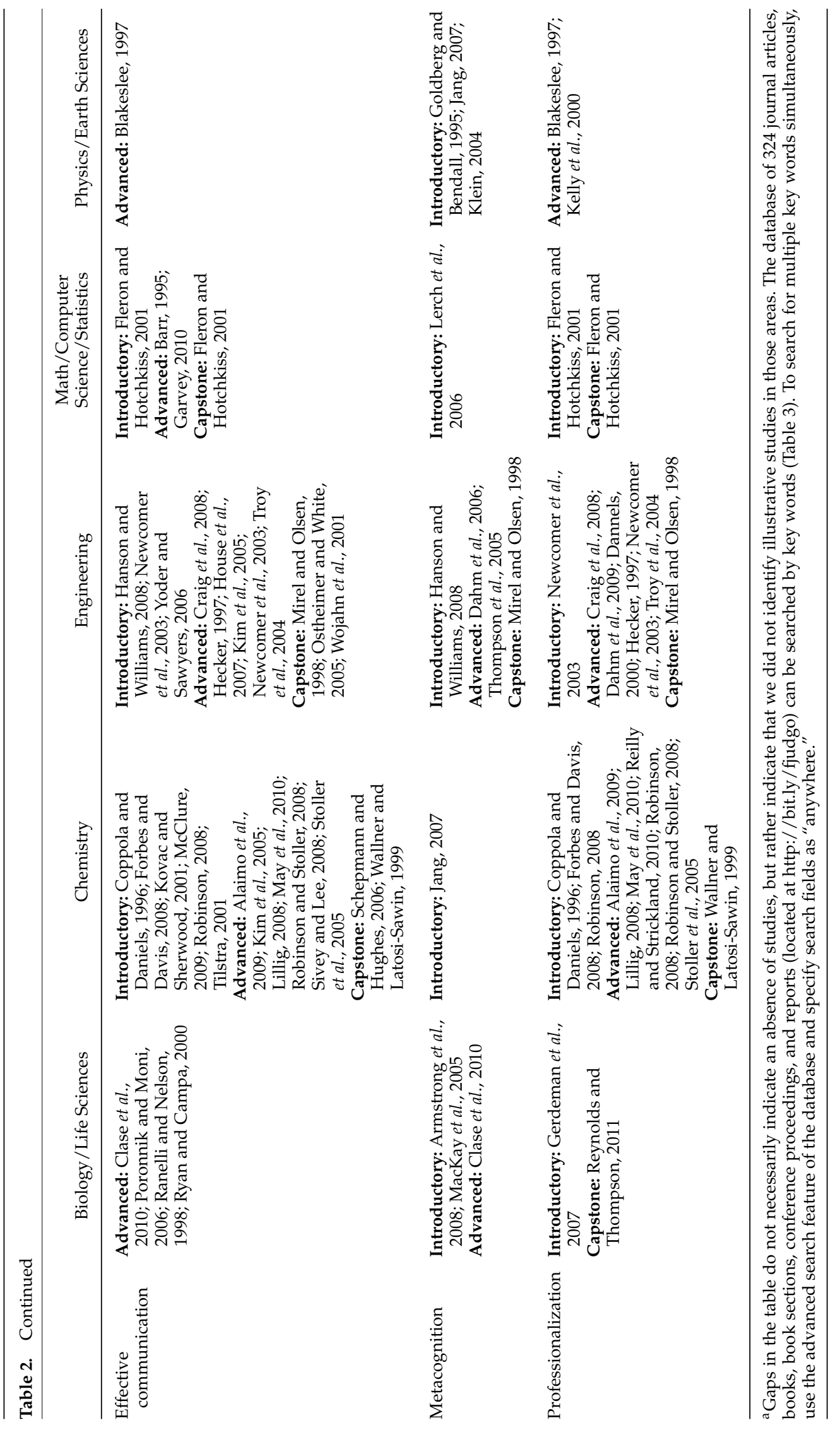


Table 3. Key words used to organize and search WTL in STEM bibliography database

\begin{tabular}{|c|c|c|}
\hline $\begin{array}{l}\text { Discipline } \\
\text { - Biology and Life Sciences } \\
\text { - Chemistry } \\
\text { - Engineering } \\
\text { - Math, Computer Science, and Statistics } \\
\text { - Physics and Earth Science }\end{array}$ & $\begin{array}{l}\text { Research level } \\
\text { - Descriptive } \\
\text { - Analytic } \\
\text { - Experimental } \\
\text { - Meta-analysis } \\
\text { - Review }\end{array}$ & $\begin{array}{l}\text { Assignment type } \\
\text { - CPR } \\
\text { - Grant proposals } \\
\text { - Group project } \\
\text { - In-class writing } \\
\text { - Journal articles (includes } \\
\text { journal-style papers) }\end{array}$ \\
\hline $\begin{array}{l}\text { Level } \\
\text { - Introductory } \\
\text { - Advanced } \\
\text { - Capstone }\end{array}$ & $\begin{array}{l}\text { Research methods } \\
\text { - Assessment } \\
\text { - Analysis of assignments } \\
\text { - Comparison groups } \\
\text { - Discourse analysis }\end{array}$ & $\begin{array}{l}\text { - Journaling } \\
\text { - Lab report } \\
\text { - Literature review } \\
\text { - Multimedia project } \\
\text { - Multiple assignments }\end{array}$ \\
\hline $\begin{array}{l}\text { Learning outcomes } \\
\text { - Content knowledge } \\
\text { - Conceptual understanding } \\
\text { - Scientific method } \\
\text { - Critical thinking } \\
\text { - Communication } \\
\text { - Metacognition } \\
\text { - Professionalization (includes "disciplinary ways of knowing") }\end{array}$ & $\begin{array}{l}\text { - Evaluations } \\
\text { - Exams } \\
\text { - Focus groups } \\
\text { - Grounded analysis } \\
\text { - Interviews } \\
\text { - Qualitative } \\
\text { - Quantitative analysis } \\
\text { - Rubric } \\
\text { - Survey } \\
\text { - Think-aloud protocols }\end{array}$ & $\begin{array}{l}\text { - Op/ed (includes position papers) } \\
\text { - Peer review } \\
\text { - Reflective essay } \\
\text { - Research proposal } \\
\text { - Short paper } \\
\text { - Summary } \\
\text { - Synthesis } \\
\text { - Term paper } \\
\text { - Thesis } \\
\text { - Ungraded writing } \\
\text { - Writing for publication }\end{array}$ \\
\hline
\end{tabular}

and therefore serve as potential intervention targets for WTL practices. Cognition involves the skills to encode and recall information: rehearsal, elaboration, organization, and comprehension-monitoring learning strategies (Weinstein and Mayer, 1985); and the processes of problem solving and critical thinking (Schraw et al., 2006). Metacognition involves planning, monitoring, and evaluating one's cognitive processes. Motivation involves those prior beliefs and attitudes that affect engagement with the task and the development and use of cognitive and metacognitive processes (Schraw et al., 2006). Emotion involves anxiety associated with performance, for example test anxiety or stereotype threat, and the notion of "troublesome knowledge," that is, when learning involves transformations in beliefs, commitments, and matters of identity (Meyer and Land, 2005). Although several studies have looked at the impact of metacognition in writing to promote learning gains (Thompson et al., 2005; Armstrong et al., 2008, Hanson and Williams, 2008), mechanisms of effect are rarely considered in WTL research in STEM (although Shah et al., 2009 , is a notable example of how mechanisms could be studied).

Fourth, the extant evidence supports the effectiveness of two types of WTL assignments in particular for improving learning in STEM disciplines: 1) Assignments that focus critical reflection on one's epistemic beliefs regarding knowledge and understanding, problem solving, and application of knowledge (e.g., Bangert-Drowns et al., 2004, Lerch et al., 2006); and 2) assignments that engage the student in formulating a reasoned argument (e.g., Kelly et al., 2000; Bradley, 2001; Kelly and Takao, 2002; Lerner, 2007; Armstrong et al., 2008).

Fifth, we urge the adoption of a "hybrid" research paradigm that builds on the insights, methods and rubrics, and interpretative frameworks that characterize WTL scholarship in the humanities and social sciences, while promoting the hypothesis testing, controls, and experimental paradigm typical of the cognitive and natural sciences (Van Maanen, 1988; Lave and Wenger, 1991; Kirsch and Sullivan, 1992; Handelsman et al., 2004; Schell and Rawson, 2010). Such a "hybrid paradigm" would encourage multifactorial analytical and experimental-level studies that investigate and compare the impact of WTL practices on disciplinary-specific learning outcomes, using qualitative as well as quantitative assessment methods, as a function of hypothesized mediating and moderating variables, including emotional and motivational factors and learning context.

Finally, to address the gap between research and practice, we recommend that, in reporting on their work, researchers give attention to the kind of classroom situations and goals for which a specific WTL strategy is intended. Such information is necessary if practitioners are going to be confident in their choice and implementation of an intervention.

Rivard's conviction that "The area of writing to learn in science is ideal for developing collaborative projects in classroom inquiry" (p. 976) remains as true today as it was $18 \mathrm{yr}$ ago. What is different is that the combination of the emerging community of WTL/ STEM educators, a learning-based conceptual framework, the database resulting from our heuristic review, and the adoption of the hybrid paradigm enables and empowers collaborative multi-university initiatives involving multidisciplinary teams of investigators to formulate and implement common protocols across multiple settings.

\section{ACKNOWLEDGMENTS}

We thank all the participants of our WTL workshop, and especially the other members of our working group: Greg Bothun, David Hanson, Jeffery Kovac, Lisa McNair, Tamara Moore, Marie Paretti, Arlene Russell, and Leslie Schiff. We also thank Leo Gafney for acting as the external evaluator for the WTL workshop, Annaliese Franz for suggesting valuable references for the database, and Teddy Gray for 
help in synchronizing our database with a stable, searchable online database. This work was funded in part by NSF grant 000215159 .

\section{REFERENCES}

Alaimo P, Langenhan J, Nichols L (2009). Eliminating lab reports: a rhetorical approach for teaching the scientific paper in sophomore organic chemistry. WAC J 20, 17-32.

Allie S, Demaree D, Taylor J, Lubben F, Buffler A (2008). Making sense of measurements, making sense of the textbook. In: 2008 Physics Education Research Conference, vol. 1064, eds. M. Henderson, M. Sabella, and L. Hsu, 3-6.

Armstrong NA, Wallace CS, Chang SM (2008). Learning from writing in college biology. Res Sci Educ 38, 483-499.

Bangert-Drowns RL, Hurley MM, Wilkinson B (2004). The effects of school-based writing-to-learn interventions on academic achievement: a meta-analysis. Rev Educ Res 74, 29-58.

Barr TH (1995). Integrating mathematical ideas through reading, writing, and speaking: a senior seminar in mathematics and computer science. PRIMUS 5(1), 43-54.

Bean J, Weimer M (2011). Engaging Ideas: The Professor's Guide to Integrating Writing, Critical Thinking, and Active Learning in the Classroom, San Francisco: Jossey Bass.

Bereiter C, Scardamalia M (1987). The Psychology of Written Composition, Hillsdale, NJ: Lawrence Erlbaum.

Berry FC, Carlson PA (2010). Assessing engineering design experiences using calibrated peer review. Int J Eng Educ 26(6).

Beyer CH, Gillmore G, Fisher AT (2007). Inside the Undergraduate Experience: The University of Washington's Study of Undergraduate Learning, Bolton, MA: Anker Publishing.

Blakemore S-J, Chowdhury S (2006). Development of the adolescent brain: implications for executive function and social cognition. JChild Psychol Psychiatry 47, 296-312.

Blakeslee A. (1997). Activity, context, interaction, and authority: learning to write scientific papers in situ. J Business Tech Commun 11, 125-169.

Bommaraju S (2004). Effective writing assignments to enhance student learning in "Introduction to Circuit Analysis." Paper presented at the American Society for Engineering Education Annual Conference and Exposition.

Bradley DB (2001). Developing research questions through grant proposal development. Educ Gerontol 27, 569-581.

Bressette AR, Breton GW (2001). Using writing to enhance the undergraduate research experience. J Chem Educ 78(12), 16261627.

Brewster C, Klump J (2004). At the classroom level: writing in the disciplines and writing to learn, In: Writing to Learn, Learning to Write: Revisiting Writing across the Curriculum in Northwest Secondary Schools, Portland, OR: Northwest Regional Educational Laboratory, 19-23.

Brod R, Gomber J, Mendoza J, Roginski J, Smith T (2010). Modeling a day in the life of a diabetic. PRIMUS 20(3), 261-273.

Burke KA, Greenbowe TJ, Hand BM (2006). Implementing the science writing heuristic in the chemistry laboratory. J Chem Educ 83(7), 1032-1038.

Carter M, Ferzli M, Wiebe EN (2007). Writing to learn by learning to write in the disciplines. J Bus Tech Commun 21, 278-302.

Clase KL, Gundlach E, Pelaez NJ (2010). Calibrated peer review for computer-assisted learning of biological research competencies. Biochem Mol Biol Educ 38(5), 290-295.
Codespoti DJ (1994). The capstone of the C.S. Major. In: Recreating the Revolution. Proceedings of the 15th Annual National Educational Computing Conference (Boston, MA, June 13-15, 1994).

Cooper MM (1993). Writing: an approach for large-enrollment chemistry courses. J Chem Educ 70, 476-477.

Coppola BP, Daniels DS (1996). The role of written and verbal expression in improving communication skills in an undergraduate chemistry program. Language Learning across Disciplines 1, 67-86.

Craig JL, Lerner N, Poe M (2008). Innovation across the curriculum: Three case studies in teaching science and engineering communication. IEEE Trans Professional Commun 51(3), 280-301.

Cummings K, Murphy M (2007). The effectiveness of incorporating conceptual writing assignments into physics instruction. In: 2006 Physics Education Research Conference, vol. 883, eds. L. McCullough, L. Hsu, and P. Heron, 61-64.

Dahm K, Newell J, Harvey R (2006). Developing metacognitive engineering teams through targeted writing exercises and studying learning preferences. Paper presented at the American Society for Engineering Education Annual Conference and Exposition, Chicago, IL.

Dahm K, Newell J, Newell H, Harvey R (2009). The impact of structured writing and developing awareness of learning preferences on the performance and attitudes of engineering teams. Adv Eng Educ 1(4), 1-17.

Dannels D. P (2000). Learning to be professional: technical classroom discourse, practice, and professional identity construction. J Business Tech Commun 14(1), 5-37.

Elbow P, Belanoff P (1999). Sharing and Responding, New York: McGraw-Hill.

Ferris D (2003). Response to Student Writing: Implications for Second Language Students, New York: Routledge.

Fleron JF, Hotchkiss PK (2001). First-year and senior seminars: Dual seminars = stronger mathematics majors. PRIMUS 11(4), 289-324.

Forbes DC, Davis PM (2008). Forging faculty-student relationships at the college level using a first-year research experience. J Chem Educ 85(12), 1696-1698.

Ganguli AB (1994). Writing to learn mathematics: enhancement of mathematical understanding. AMATYC Rev 16, 45-51.

Garvey A (2010). Writing in an upper-level cs course. Proceedings of the 41st ACM Technical Symposium on Computer Science Education, 209-213.

Gerdeman RD, Russell AA, Worden KJ (2007). Web-based student writing and reviewing in a large biology lecture course. J Coll Sci Teach 36(5), 46-52.

Goldberg, F, Bendall S (1995). Making the invisible visible- a teaching/learning environment that builds on a new view of the physics learner. Am J Phys 63(11), 978-991.

Graham S, Perin D (2007). Writing next: effective strategies to improve writing of adolescents in middle and high schools, Washington, DC: Alliance for Excellent Education.

Guisasola J, Ceberio M, Zubimendi JL (2006). University students' strategies for constructing hypothesis when tackling paper-and-pencil tasks in physics. Res Sci Educ 36(3), 163186.

Handelsman J, et al. (2004). Scientific teaching. Science 304, 521-522.

Hanson JH, Williams JM (2008). Using writing assignments to improve self-assessment and communication skills in an engineering statics course. J Eng Educ 97, 515-529.

Hecker PA (1997). Successful consulting engineering: a lifetime of learning. J Manage Eng 13(6), 62-65. 
House R, Watt A, Williams JM (2007). Mapping the Future of Engineering Communication: Report on a Research Study of Engineering Faculty and Their Teaching of Writing as a Function of the ABET/EAC Criteria. Paper presented at the International Professional Communication Conference, Seattle, WA.

Jang SJ (2007). A study of students' construction of science knowledge: talk and writing in a collaborative group. Educ Res 49(1), 65-81.

Kelly GJ, Chen C, Prothero W (2000). The epistemological framing of a discipline: writing science in university oceanography. J Res Sci Teach 37, 691-718.

Kelly GJ, Takao A (2002). Epistemic levels in argument: an analysis of university oceanography students' use of evidence in writing. Sci Educ 86, 314-342.

Kim SH, Wise J, Hillsley M (2005). Learning technical writing skills through peer review: use of calibrated peer review ${ }^{\mathrm{TM}}$, in unit operation lab. Paper presented at the AIChE Annual Meeting, Conference Proceedings.

Kirsch G, Sullivan P (1992). Methods and Methodology in Composition Research, Carbondale: Southern Illinois University Press.

Klein PD (2004). Constructing scientific explanations through writing. Instruct Sci 32(3), 191-231.

Kovac J, Sherwood DW (2001). Writing across the chemistry curriculum: an instructor's manual, Prentice Hall.

Kuhn D (1999). A developmental model of critical thinking. Educ Res $28,16-26$.

Kuhn D (2005). Education for Thinking, Cambridge, MA: Harvard University Press.

Lave J, Wenger E (1991). Situated Learning: Legitimate Peripheral Participation, Cambridge: Cambridge University Press.

Lerch C, Bilics A, Colley B (2006). Using Reflection to Develop Higher Order Processes. Paper presented at the Annual Meeting of the American Education Research Association, San Francisco, CA, April 2006

Lerner N (2007). Laboratory lessons for writing and science. Writ Commun 24, 191-222.

Lillig JW (2008). Writing across the semester: a non-standard term paper that encourages critical data analysis in the upper-division chemistry classroom. J Chem Educ 85, 1392-1394.

MacKay MB, Emerson L, Funnell KA, MacKay BR (2005). Journal writing as a tool for learning in landscape management and horticultural science. In: IVth International Symposium on Horticultural Education, Extension and Training-Proceedings, eds. Z. Singh, P. J. Batt, R. MurrayPrior, 233-239.

Margerum LD, Gulsrud M, Manlapez R, Rebong R, Love A (2007). Application of calibrated peer review (CPR) writing assignments to enhance experiments with an environmental chemistry focus. J Chem Educ 84(2), 292-295.

May CL, Locke JR, Coppola BP, McNeil AJ (2010). Improving science education and understanding through editing wikipedia. J Chem Educ 87, 1159-1162.

Mayer RE (1992). Cognition and instruction: their historic meeting within educational psychology. J Educ Psychol 84, 405-412.

McClure C (2009). Introducing scientific writing to students early in their academic careers. J Coll Sci Teach 38, 20-23.

Meyer JHF, Land R (2005). Threshold concepts and troublesome knowledge (2): epistemological considerations and a conceptual framework for teaching and learning. Higher Educ 49, 373-388.

Mirel B, Olsen LA (1998). Social and cognitive effects of professional communication on software usability. Tech Commun Quarterly 7(2), 197-221.
Moskovitz C, Kellogg D (2011). Inquiry-based writing in the laboratory course. Science 332, 919-920.

National Research Council (2000). How People Learn: Brain, Mind, Experience, and School, Washington, DC: National Academies Press.

National Survey of Student Engagement (2008). Promoting Engagement for All Students: The Imperative to Look Within. http:/ / nsse.iub.edu/NSSE_2008_Results/docs/withhold/NSSE2008_Results _revised_11-14-2008.pdf (accessed 20 March 2009).

Nekvasil NP (1998). Using round table labs to complement didactic lectures and experimental labs. Adv Physiol Educ 19(1) S68S73.

Newcomer J, Kitto K, Sylvester B (2003). Written communication in a technical context: meaningful writing assignments for engineering technology students. Paper presented at the ASEE/IEEE Frontiers in Education Conference, Boulder, CO.

Ostheimer MW, White EM (2005). Portfolio assessment in an American engineering college. Assessing Writing 10(1), 61-73.

Pelaez NJ (2002). Problem-based writing with peer review improves academic performance in physiology. Adv Physiol Educ 26(3), 174184.

Poirrier GP (1997). Writing-to-Learn: Curricular Strategies for Nursing and Other Disciplines, New York: National League of Nursing Press.

Poock JR, Burke KA, Greenbowe TJ, Hand BM (2007). Using the science writing heuristic in the general chemistry laboratory to improve students' academic performance. J Chem Educ 84(8), 13711379.

Poronnik P, Moni RW (2006). The opinion editorial: teaching physiology outside the box. Adv Physiol Educ 30(2), 73-82.

Ranelli PL, Nelson JV (1998). Assessing writing perceptions and practices of pharmacy students. Am J Pharmaceut Educ 62(4), 426432.

Reilly JT, Strickland M (2010). A writing and ethics component for a quantum mechanics, physical chemistry course. J Coll Sci Teach 39, 35-41.

Reynolds JA, Thompson RJ Jr. (2011). Want to improve undergraduate thesis writing? Engage students and their faculty readers in scientific peer review CBE Life Sci Educ 10, 209215.

Ridgway D, Young V (2005). Applying a writing-to-learn strategy in a traditional material science and engineering course. Paper presented at the American Society for Engineering Education Annual Conference and Exposition, Portland, OR.

Rivard LP (1994). A review of writing to learn in scienceimplications for practice and research. J Res Sci Teach 31, 969983.

Robinson MS (2008). Using the ACS journals search to validate assumptions about writing in chemistry and improve chemistry writing instruction. J Chem Educ 85(5), 650-654.

Robinson MS, Stoller FL (2008). Write like a chemist, New York: Oxford University Press.

Rosenthal LC (1987). Writing across the chemistry curriculum: chemistry lab reports. J Chem Educ 64, 996.

Rudd J A III, Wang VZ, Cervato Cl, Ridkey R (2009). Calibrated peer review ${ }^{\mathrm{TM}}$ assignments for the earth sciences. J Geosci Educ 57, 324-4328.

Russell A (2005). Calibrated Peer Review ${ }^{\mathrm{TM}}$ : a writing and criticalthinking instructional tool. In: Invention and Impact: Building Excellence in Undergraduate Science, Technology, Engineering and Mathematics (STEM) Education, Washington, DC: American Association for the Advancement of Science, 67-71. 
Ryan MR, Campa H (2000). Application of learner-based teaching innovations to enhance education in wildlife conservation. Wildlife Soc Bull 28(1), 168-179.

Schell E, Rawson, KJ (2010). Rhetorica in Motion: Feminist Rhetorical Methods and Methodologies, Pittsburgh, PA: University of Pittsburgh Press.

Schepmann HG, Hughes LA (2006). Chemical research writing: a preparatory course for student capstone research. J Chem Educ 83(7), 1024-1028.

Schoenfeld AH (1999). Looking toward the 21st century: challenges of educational theory and practice. Educ Res 28, 4-14.

Schraw G, Crippen KJ, Hartley K (2006). Promoting self-regulation in science education: metacognition as part of a broader perspective on learning. Res Sci Educ 36, 111-139.

Scoles K, Millan H (2005). Bringing writing into the ECE laboratory. Paper presented at the American Society for Engineering Education Annual Conference and Exposition, Portland, OR.

Shah J, Shah A, Pietrobon R (2009). Scientific writing of novice researchers: what difficulties and encouragements do they encounter? Acad Med 84, 511-516.

Shibley IA, Milakofksy LM, Nicotera CL (2001). Incorporating a substantial writing assignment into organic chemistry: library research, peer review, and assessment. J Chem Educ 78, 50-53.

Sivey JD, Lee CM (2008). Using popular magazine articles to teach the art of writing for nontechnical audiences. J Chem Educ 85, 5558.

Spear K (1987). Sharing Writing, Portsmouth, NH: Boynton/ Cook/Heinemann.

Stewart J, Ballard S (2010). Effect of written presentation on performance in introductory physics. Phys Rev Special Topics-Phys Educ Res 6(2).

Stoller FL, Horn B, Grabe W, Robinson MS (2005). Creating and validating assessment instruments for a discipline-specific writing course: an interdisciplinary approach. J Appl Linguistics 2, 75-104.

Thaiss C (1998). The Harcourt Brace Guide to Writing across the Curriculum, Fort Worth, TX: Harcourt Brace Jovanovich.

Thaiss C, Zawacki T (2006). Engaged Writers and Dynamic Disciplines: Research on the Academic Writing Life, Portsmouth, NH: Boynton/Cook/Heinemann.
Thompson N, Alford E, Liao C, Johnson R, Matthews M (2005). Integrating undergraduate research into engineering: a communications approach to holistic education. J Eng Educ 94, 297-308.

Tilstra L (2001). Using journal articles to teach writing skills for laboratory reports in general chemistry. J Chem Educ 78(6), 762-764.

Troy J, Hirsch P, Smith H, Yalvac B (2004). Team-based written communication exercises for biomedical engineering juniors: where to do it and what works. Paper presented at the American Society for Engineering Education Annual Conference and Exposition, Salt Lake City, UT.

Van Maanen J (1988). Tales of the Field: On Writing Ethnography, Chicago, IL: University of Chicago Press.

Volz T, Saterbak A (2009). Students' strengths and weaknesses in evaluating technical arguments as revealed through implementing Calibrated Peer Review ${ }^{\mathrm{TM}}$ in a bioengineering laboratory. http://wac.colostate.edu/atd/technologies/volz_saterbak.cfm (accessed 3 October 2011).

Wallner AS, Latosi-Sawin E (1999). Technical writing and communication in a senior-level chemistry seminar. J Chem Educ 76(10), 1404-1406.

Walvoord ME, Hoefnagels MH, Gaffin DD, Chumchai MM, Long DA (2008). An analysis of calibrated peer review (CPR) in a science lecture classroom. J Coll Sci Teach 38, 66-72.

Weinstein CE, Mayer RE (1985). The teaching of learning strategies, In: Handbook of Research on Teaching, ed. M.C. Wittrock, New York: Macmillan, 315-327.

Whelan RJ, Zare RN (2003). Teaching effective communication in a writing-intensive analytical chemistry course. J Chem Educ 80(8), 904-906.

Wojahn P, Dyke J, Riley LA, Hensel E, Brown SC (2001). Blurring boundaries between technical communication and engineering: challenges of a multidisciplinary, client-based pedagogy. Tech Commun Quarterly 10(2), 129-148.

Yalvac B, Smith HD, Troy JB, Hirsch P (2007). Promoting advanced writing skills in an upper-level engineering class. J Eng Educ 96(2), 117-128.

Yoder J, Sawyers D (2006). Proofreading exercises to improve technical writing in a freshman engineering course. Paper presented at the American Society for Engineering Education Annual Conference and Exposition, Chicago, IL. 